\title{
Enfermedad de Castleman de localizacion cervical
}

\section{Cervical Castleman's disease}

\author{
M.T. Martínez Iturriaga', M.E. Reguero Callejas², A. Prieto Fenech³, I. Alvarez ${ }^{4}$, E. Sánchez-Jauregis, \\ J.L. Martínez Laje
}

Resumen: La enfermedad de Castleman se caracteriza por la presencia de masas de tejido linfático; existen dos variedades la hialino vascular $91 \%$ (localizada) y plasmática $9 \%$ (multicéntrica).

Presentamos un varón de 30 años con tumoración latero cervical izquierda indolora. Se realizó una exéresis total de la lesión.

La histología es Enfermedad Castleman variante hialino vascular.

La enfermedad de Castleman se presenta fundamentalmente en el tejido linfático mediastínico. La localización cervical es muy rara. Se debe realizar un estudio de extensión para descartar la forma multicentrica de la enfermedad. En la forma localizada la extirpación de la lesión implica la curación de la enfermedad.

Palabras clave: Enfermedad de Castleman; Masa cervical; Tejido linfático.

Recibido: 23.10 .06

Aceptado: 04.06 .07

\begin{abstract}
Castleman's Disease is characterized by the presence of lymphatic tissue masses. There are two forms the hyaline vascular 91\% (unifocal) and the plasmatic 9\% (multifocal).

We present a 30 year old man with a left laterocervical painless mass. Total resection of the tumour was performed.

The histological result was Castleman's disease hyaline vascular form. Castleman's disease presents mainly in the lymphatic tissue of the mediastinum. Cervical location is very rare. Periphery metastasis work up must be done to rule out the multifocal form of the disease. Surgical excision is curative for the unifocal form.
\end{abstract}

Key words: Castleman's disease; Cervical mass; Lymphatic tissue.

\footnotetext{
1 Médico Residente. Servicio de Cirugía Oral y Maxilofacial

2 Médico Residente. Servicio de Anatomía Patológica

3 Jefe de Sección. Servicio de Cirugía Oral y Maxilofacial

4 Médico adjunto. Servicio de Cirugía Oral y Maxilofacial

5 Médico Residente. Servicio de Cirugía Oral y Maxilofacial

6 Jefe de Servicio. Servicio de Cirugía Oral y Maxilofacial

Hospital Ramón y Cajal. Madrid, España
}

\section{Correspondencia:}

Dra. M.T. Martínez Iturriaga

C/Julio Caro Baroja 84,

28050 Madrid, España

Email: 1@colmeitu.e.telefonica.net 


\section{Introducción}

La enfermedad de Castleman (hiperplasia gigante del ganglio linfático, hamartoma ganglionar linfático) es un raro trastorno que representa una forma particular de hiperplasia linfoide más que un tumor o un hamartoma. Su origen es desconocido caracterizado por la presencia de masas seudo tumorales de tejido linfático. Aparece en niños o adultos jóvenes sin predominancia por el sexo o la raza.

Fue descrito por primera vez en 1954 y posteriormente caracterizado por Castleman en 1956.1-3

Existen dos variedades: la hialino-vascular (91\%) caracterizada por la gran proliferación folicular con cambios hialino-vascular en los centros germinales del ganglio linfático y que suele afectar al mediastino. La otra variante es la de células plasmáticas (9\%) que se caracteriza por la proliferación de células plasmáticas en las áreas ínter foliculares del ganglio sin que aparezcan cambios hialino-vasculares en los folículos, esta forma suele ser extramediastínica. Hay además una tercera forma mixta muy poco frecuente. ${ }^{4}$

El caso presentado es de localización extramediastínica siendo esto altamente infrecuente al tratarse de la variante hialino-vascular cuya localización habitual es la mediastínica.

\section{Caso clínico}

Presentamos a un varón de 30 años, sin antecedentes médicoquirúrgicos de interés, que consultó por tumoración latero-cervical izquierda de varios meses de evolución; el paciente refería sudoración nocturna en los últimos meses como único dato destacable de la anamnesis.

A la exploración se apreciaba una tumoración de aproximadamente $5 \times 5 \mathrm{~cm}$ de diámetro medial al tercio inferior del músculo esternocleidomastoideo (ECM) de consistencia elástica, mal definida, no adherida a planos profundos ni a piel, cuyo tamaño no variaba con los cambios posturales, no pulsátil, y con auscultación negativa.

Se solicitó una punción guiada por tomografía computerizada (TC) que se informó como celularidad de ganglio lifático con cambios indeterminados no tipificables citologicamente, recomendando estudio serológico viral.

En la TC con contraste intravenoso se apreciaba una masa homogénea, de $5 \times 7 \mathrm{~cm}$, sólida, bien delimitada, situada en el espacio vascular cervical izquierdo que comprime la vena yugular interna izquierda, por detrás del ECM, con captación de contraste moderada y con alguna adenopatía adyacente (Fig. 1). No llegaba a tener una hipercaptación sugerente de glomus carotídeo. El diagnóstico diferencial radiológico incluía proceso linfoproliferativo, tumor neurógeno o tumor mesenquimal.

Bajo anestesia general se realizó una incisión horizontal supraclavicular izquierda y sección del músculo ECM a dicho nivel para obtener una adecuada exposición. Se encontró una tumoración de $5 \times 7 \mathrm{~cm}$ de aspecto congestivo, dura con intensa vascularización periférica que dificultaba la disección de la misma; la tumoración presentaba un plano de separación con el espacio vascular. El aspecto clínico en el momento de la cirugía impresionó a los autores de tumoración vascular (Fig. 2).

\section{Introduction}

Castleman's disease (giant lymph node hyperplasia, lymph node hamartoma) is a rare disorder that is more a particular form of lymphoid hyperplasia than a tumor or hamartoma. The tumor is of unknown origin and it is characterized by the presence of pseudotumoral masses of lymphatic tissue. It occurs in children or young adults and has no sexual or racial predominance.

It was first described in 1954 and later characterized by Castleman in 1956..$^{1-3}$

Two varieties exist. The vascular hyaline variety (91\%) is characterized by intense follicular proliferation with hyaline vascular changes in the germinal centers of the lymph node. It usually affects the mediastinum. The other one is the plasma cell variety (9\%), which is characterized by the proliferation of plasma cells in the interfollicular areas of the lymph node without hyaline vascular changes in the follicles. This form is usually extramediastinal. A very infrequent mixed form also exists. ${ }^{4}$

The case presented here involved an extramediastinal location, which is highly uncommon for the hyaline vascular variant, which is usually located in the mediastinum.

\section{Clinical case}

A 30-year-old man without a medical or surgical history of interest consulted for a left lateral cervical tumor of several months' evolution. The patient referred nocturnal sweating in recent months as the only notable finding in his history.

In the examination, a tumor of $5 \times 5 \mathrm{~cm}$ diameter was found medial to the lower third of the sternocleidomastoid muscle (SCM). It was of elastic consistency, poorly defined, not adhered to deep planes or to skin, did not vary in size with postural changes, was nonpulsatile, and had negative auscultation.

Fine needle aspiration biopsy guided by computed tomography (CT) was requested. It was reported as lymph node cellularity with indeterminate changes that were not cytologically typifiable. Viral serologic study was recommended.

CT with intravenous contrast revealed a homogeneous, solid, well delimited, $5 \times 7 \mathrm{~cm}$ mass that was located in the left cervical vascular space and compressed the left internal jugular vein behind the SCM. It showed moderate contrast uptake and some adjacent enlarged lymph nodes (Fig. 1). The mass did not exhibit the increased uptake of carotid glomus. The radiographic differential diagnosis included lymphoproliferative process, neurogenic tumor, and mesenchymal tumor.

A horizontal left supraclavicular incision was made under general anesthesia and the SCM muscle was sectioned at the same level to obtain adequate exposure. A $5 \times 7 \mathrm{~cm}$ tumor of congestive appearance was found. It was hard and had prolific peripheral vascularization that made dissection difficult. The tumor had a plane of separation from the vascular space. 
En el estudio anatomopatológico de la pieza se comprobó que se trataba de un ganglio linfático con arquitectura conservada y marcado aumento del número de folículos linfoides (Fig. 3) y positividad para marcadores inmunohistoquímicos (CD20+CD10+, bcl2-) (Fig. 4). De forma característica los centros germinales presentaban un material hialino, algunos vasos y disposición en capas de cebolla de la corona linfocitaria (Fig. 5).

El número de células plasmáticas (CD138) estaban en el rango de la normalidad y no muestraban restricción para las cadenas ligeras de las inmunoglobulinas (kappa y lambda).

En el estudio molecular no se detectó mediante técnica de PCR la presencia del virus herpes humano tipo 8 (HHV 8).

Se realizó TC toraco-abdomino-pélvico que resultó dentro de la normalidad. La analítica completa, estudio inmunológico y serología fueron normales.

Estos hallazgos representan la forma localizada de la hiperplasia angiofolicular linfoide o Enfermedad de Castleman, variante hialino-vascular.

\section{Discusión}

Los múltiples nombres (hamartoma ganglionar linfático, hiperplasia gigante del ganglio linfático, hiperplasia angiofolicular linfoide, linfoma de Castleman, etc) con los que se ha denominado a la enfermedad de Castleman demuestran el origen todavía incierto de su patogénesis. Puede presentarse desde los 2 hasta los 71 años, siendo más frecuente en adultos. Las lesiones pueden presentarse en el tórax (60\%), cuello (14\%), abdomen (30\%) y axila (4\%).

La enfermedad de Castleman puede presentarse de forma local y unicéntrica siendo esta benigna y con resolución tras resección quirúrgica de la masa linfática $80-90 \%$ o de forma extendida y multicéntrica con síntomas sistémicos y un curso clínico más agresivo 10-20\%. ${ }^{5}$

La localización más frecuente de esta proliferación linfática probablemente reactiva es la mediastínica (60\%) seguida de la abdominal (14\%), cervical (13\%), axila (4\%) aunque puede aparecer en cualquier lugar donde existan ganglios linfáticos existiendo casos publicados en la glándula parótida, páncreas, glándulas suprarrenales, hígado, pene y vulva.2,6 En el territorio maxilofacial la localización más frecuente es en los ganglios linfáticos del cuello. En la literatura encontramos afectación parotídea (7 casos), glándula submaxilar ( 2 casos), suelo de boca ( 1 caso), espacio parafaringeo (1 caso), laringe (1 caso), paladar (1 caso).

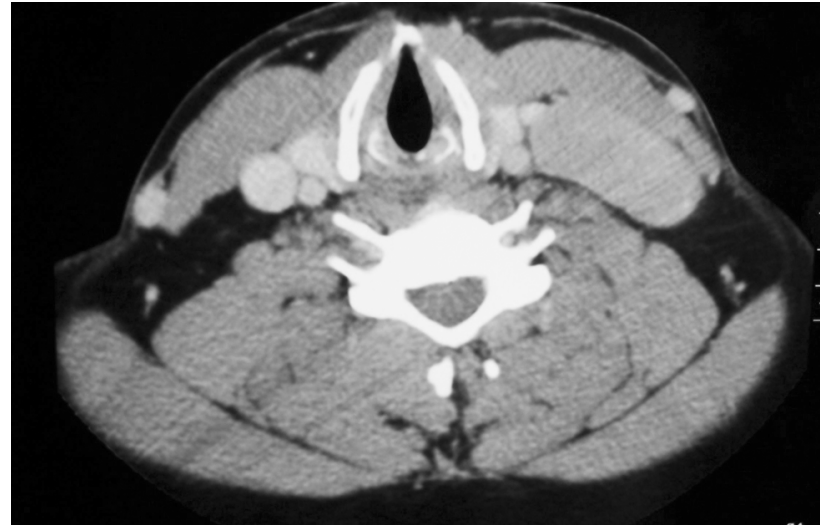

Figura 1.TC corte axial con contraste intravenoso. Masa homogénea de $5 \times 7 \mathrm{~cm}$, sólida, bien delimitada, situada en el espacio vascomprime la vena yugular interna

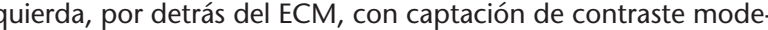
Figure 1. Axial CT slices with intravenous contrast. A homogeneous, space, which compresses the left internal jugular vein behind the sternocleicomastoid muscle, with moderate contrast uptake and some adjacent enlarged lymph nodes.

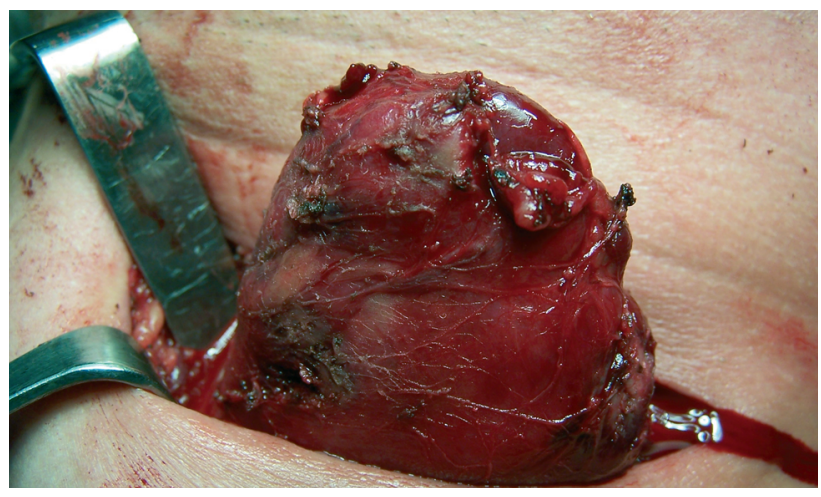

Figura 2. Imagen intra operatoria de la tumoración. Figure 2. Intraoperative image of the tumor.
The clinical appearance at the time of the intervention impressed the authors as characteristic of a vascular tumor (Fig. 2).

The histopathologic study of the piece confirmed that it was a lymph node with conserved architecture, a marked increase in the number of lymphoid follicles (Fig. 3), and positivity for immunohistochemical markers (CD20+CD10+, bcl2-) (Fig. 4). Characteristically, the germinal centers presented hyaline material, vessels, and an "onion-layer" disposition of the lymphocyte crown (Fig. 5).

The number of plasma cells (CD138) was within the range of normality and showed no restriction for immunoglobulin light chains (kappa and lamda).

In the molecular study, the PCR technique did not detect the presence of human herpes virus type 8 (HHV 8).

Thoraco-abdomino-pelvic CT showed results within the range of normality. The complete analytical study, immunological study, and serology were normal.

These findings were consistent with the localized form of lymphoid angiofollicular hyperplasia, or Castleman's disease, hyaline vascular variant.

\section{Discussion}

The many names (lymph node hamartoma, giant lymph node hyperplasia, lymphoid angiofollicular hyperplasia, Castleman's lymphoma, etc) by which Castleman's disease is known demonstrate that the pathogenesis of the condition is still uncertain. It occurs between the ages of 2 and 71 years and is more frequent in adults. The lesions can appear in thorax (60\%), neck (14\%), abdomen (30\%), and axilla (4\%).

Castleman's disease can occur in a local and single-focus form (80-90\%), which is benign and resolves after surgical resection of the lymphatic mass, or in an extended and multifocal form (10-20\%) with systemic symptoms and a more 
El diagnóstico clínico de la enfermedad de Castleman cervical es difícil ya que la mayoría de los pacientes presentan únicamente una masa cervical indolora sin fiebre ni anemia. En la forma hialino vascular no suelen existir alteraciones analíticas y la punción aspiración con aguja fina (PAAF) suele ser no concluyente.

El diagnóstico se efectua tras la exéresis quirúrgica de la lesión que además resulta curativa.

Los pacientes con enfermedad de Caslteman multicéntrica presentan evidencia clínica o radiológica de afectación linfática generalizada debiéndose encontrar los hallazgos histopatológicos de la enfermedad en al menos una región linfática. Suelen ser pacientes más mayores (edad media 56 años) y presentan síntomas sistémicos como hepatoesplenomegalia, anemia hipocroma y microcítica que no responde al tratamiento con hierro, hipergammaglobulinemia, y VSG aumentada. Es posible que los ganglios linfáticos afectados segregen una sustancia antieritropoyética responsable de la anemia.

Histológicamente suelen pertenecer al tipo de células plasmáticas. La variante multicéntrica es más agresiva y puede trasformarse en un linfoma o un sarcoma de Kaposi, lo cual es excepcional en la variante hialina.

Los hallazgos radiológicos son relativamente inespecíficos.

Los hallazgos ecográficos son similares a los de un linfoma. ${ }^{11}$

En estudios angiográficos realizados se describe un intenso patrón de neovascularización periférica en la lesión ${ }^{12}$ lo cual pudimos comprobar durante la extirpación del presente caso, lo que dificultó y prolongó la intervención.

Los hallazgos en la TC revelan una masa homogénea que presenta realce temprano con contraste en la forma hialino-vascular. ${ }^{11}$ En el caso que presentamos la captación moderada excluía un glomus carotídeo.

Los hallazgos publicados de RM son muy pocos e inespecíficos. ${ }^{12}$

El paciente debe someterse a un estudio de extensión incluyendo TC tóraco-abdomino-pélvico en busca de enfermedad diseminada, analítica completa con VSG, estudio inmunológico completo y serología.

El diagnóstico diferencial debe establecerse con un linfoma, metástasis, enfermedades granulomatosas, sarcomas, quiste branquial, masa tiroidea, tumores neurales ya que éstas pueden tener imágenes radiológicas similares a la enfermedad de Castleman. ${ }^{11}$

El tratamiento debe ser quirúrgico de las masas linfáticas afectadas, lo que resulta curativo y raramente recidivan.3,14 aggressive clinical course. ${ }^{5}$ The most common location of this lymphatic proliferation, probably reactive, is the mediastinum (60\%), followed by the abdomen (14\%), neck (13\%), and axilla (4\%). However, it can appear anywhere that lymph nodes exist. Cases have been reported in the parotid gland, pancreas, adrenal glands, liver, penis, and vulva.2, 6 In the maxillofacial territory, the most frequent location is the lymph nodes of the neck. In the literature we found reports of involvement of the parotid (7 cases), submaxillary gland (2 cases), floor of the mouth (1 case), parapharyngeal space (1 case), larynx (1 case), and palate (1 case). The clinical diagnosis of cervical Castleman's disease is difficult because most patients only present a painless cervical mass without fever or anemia. In the vascular hyaline form there are usually no analytical abnormalities and the fine needle aspiration biopsy (PAAF) is generally inconclusive.

The diagnosis was made after surgical excision of the lesion, which is curative.

Patients with multifocal Castleman's disease exhibit clinical or radiological evidence of generalized lymph node involvement. Histopathologic evidence of the disease should be present in at least one lymphatic region. Patients are usually older (mean age 56 years) and have systemic symptoms like hepatosplenomegaly, hypochromic and microcytic anemia that does not respond to iron treatment, hypergammaglobulinemia, and accelerated ESR. The affected lymph nodes may secrete an antierythropoietic substance responsible for the anemia.

Histologically, the disease is usually the plasma cell type. The multifocal variant is more aggressive and can transform itself into lymphoma or Kaposi's sarcoma, which is exceptional in the hyaline variant.

The radiographic findings are relatively nonspecific.

Ultrasonographic findings are similar to those of lymphoma. ${ }^{11}$ 
El tratamiento con radioterapia no ha demostrado la desaparición ni la disminución de tamaño de las masas linfáticas..$^{2,3}$

En cabeza y cuello. El paciente que presentamos tiene un periodo de seguimiento de 16 meses en los cuales no hemos detectado signos de recidiva de la lesión.

\section{Conclusión}

La enfermedad de Castleman es un raro trastorno de los ganglios linfáticos de origen desconocido. Aunque su forma de presentación más frecuente es como masa mediastínica, debe ser tenida en cuenta en el diagnóstico diferencial de una tumoración cervical. La exéresis quirúrgica resulta curativa en la forma localizada (90\%) aunque siempre se debe hacer un estudio de extensión para descartar la forma diseminada de la enfermedad.

\section{Bibliografía}

1. Castleman B, Iverson L, Menendes V. Localized mediastinal lymph-node hyperplasia resembling thymoma. Cancer 1956;9:822-30.

2. Keller AR, Hochholzer L, Castleman B. Hyalinevascular and plasma cell types of giant lymph node hyperplasia of mediastinum and other locations. Cancer 1972; 29:670-83.

3. Bowne WB, Lewis JJ, Filippa DA, Niesvizky R, Brooks AD, Burt ME, Brennan MF.The management of unicentric and multicentric Castleman's disease: a report of 16 cases and a review of the literature. Cancer 1999;85:706-17.

4. Shahidi H, Myers JL, Kuale PA. Castleman's disease. Mayo Clinic Proc 1995;70: 969-77.

5. Herrada J, Cabanillas F, Rice L, Maning J, Pugh W. The clinical behaviour of localizad and multicentric Castleman disease. Ann Intern Med 1998;128:657.

6. Anagnostou D, Harrison CV. Angiofollicular lymph node hyperplasia (Castleman). J Clin Pathol 1972;25:306-11.

7. Gangopadhyay K, Mahasin ZZ, Kfoury H. Castleman disease (giant lymph node hyperplasia). Arch Otolaryngol Head Neck Surg 1997;123:1137.

8. Yi Al, de Tar M, Becker TS, y cols. Giant lymph node hyperplasia of the head and neck (Castleman's disease): A report of five cases. Otolaryngol Head Neck Surg 1995;113:462.

9. Goodisson DW, Carr RJ, Stirling RW. Parotid presentation of Castleman's disease: report of a case. J Oral Maxillofac Surg 1997;55:515.

10. Sanchez Cuellar A, de Pedro M, Martin-Granizo R, Berguer A. Castleman disease (giant lymph node hyperplasia) in the maxillofacial region: A report of 3 cases. J Oral Maxillofac Surg 2001;54:228-31.

11. Yamashita Y, Hirai T, Matsukawa T, Ogata I, Takahashi M. Radiological presentations of Casleman's disease. Comput Med Imaging Graph 1993;17:102-17.

12. Inoue Y, Nakamura H, Yamazaki K, Mizumoto S, Kokubu I, Mori H. Retroperitoneal Castleman's tumors of Hyaline vascular type: imaging study. Clin Imaging 1992;16:239-42.

13. de Geer G, Webb WR, Sollito R, Golden J. MR characteristics of benign lymph node enlargement in sarcoidosis and Castleman's disease. Eur J Radiol 1986; 6:145-8.

14. Germaine LM, Newhouse JH. Castleman’s disease. Clinical Imaging 2003; 27:4314. no-pelvic $C T$, in search of disseminated disease, complete blood tests with ESR, complete immunological study, and serology.

The differential diagnosis must be made with lymphoma, metastasis, granulomatous disease, sarcoma, branchial cyst, thyroid mass, and neural tumors because they may show radiographic images similar to Castleman's disease. ${ }^{11}$

Treatment of the affected lymph node masses must be surgical, which is curative; recurrence is rare. ${ }^{3,14}$

Radiation therapy has not been shown to produce disappearance or a reduction in the size of the lymphatic mass$e^{2,3}$ in head and neck.

The patient presented had a follow-up period of 16 months in which we have not detected signs of recurrence.

\section{Conclusion}

Castleman's disease is a rare disorder of the lymph nodes of unknown origin. Although its most frequent form of presentation is as a mediastinal mass, it must be considered in the differential diagnosis of cervical tumor. Surgical excision is curative in localized forms (90\%), but the extension must always be studied to rule out disseminated disease. 